\title{
Literature of the Pacific, Mainly Australian
}

\section{Peter Pierce}

\author{
Monash University
}

\begin{abstract}
This lecture is in some ways the 'lost' chapter of The Cambridge History of Australian Literature (2009), one eventually not written because the projected author could find not enough literary material even in that vast Pacific Ocean, or perhaps found - as mariners have - only far separated specks in that ocean. Yet Australian literature about the nation's Pacific littoral and the islands within the ocean and the ocean itself is varied, considerable, and often eccentric. Our greatest drinking song is Barry Humphries's 'The Old Pacific Sea'. The Japs and the jungle are the hallmarks of fiction, poetry and reportage of the Pacific War of 1942-5. New Guinea has attracted such writers as James McAuley, Peter Ryan, Trevor Shearston, Randolph Stow and Drusilla Modjeska. The short stories of Louis Becke are the most extensive and iconoclastic writing about the Pacific by any Australian. Yet the literature of the Pacific littoral seems thinner than that of the Indian Ocean. The map on the title page of Rolf Boldrewood's $A$ Modern Buccaneer (1894) shows those afore-mentioned specks in a vast expanse of water. What aesthetic challenges have Pacific writing posed and how have they been met? Have the waters of the Pacific satisfied Australians as a near offshore playground but defeated wider efforts of the imagination?
\end{abstract}

$\mathrm{I}$ $n$ the cosmology of the early Greeks, Ocean was 'the river supposed to encircle the plains of the earth'. It was also personified as one of the Titans, who, with his consort Tethys, were 'the progenitor of the gods, and parent of the rivers of the world, and of the ocean

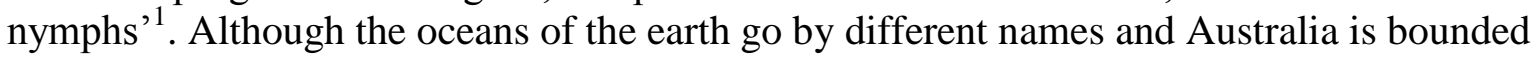
by three of them - the Pacific, the Southern and the Indian Oceans - essentially there is one world ocean, shaping, surrounding those 'plains of the earth'. The United States is oriented towards two oceanic divisions. Initially, this was the Atlantic, whence came Erik the Red, Columbus, the lost settlers of Roanoke, the Pilgrim Fathers, African slaves and those migrants and refugees whom Emma Lazarus characterised as 'Your tired, your poor,/Your huddled masses yearning to breathe free'. The journey across this ocean was arduous. Nathaniel Philbrick wrote of how 'it all started with the Atlantic Ocean. Before European settlers or African slaves laid eyes on the New World, they were forced to traverse a stormwracked wilderness that made the impenetrable forests of the American interior look like a welcoming refuge, 2 .

For William Bradford, writing of the 65-day crossing of the Mayflower in 1620, the end of the voyage, the sight of land from the ocean, was deliverance. The discovery of what lay in those soon-penetrable forests would follow. He wrote 'Being thus arrived in a good harbour and brought safe to land, they fell upon their knees and blessed the God of heaven, who had brought them across the vast and furious ocean, and delivered them from the perils and miseries thereof, again to set their feet on the firm and stable earth, their proper element' ${ }^{3}$. With a mixture of trepidation and wonder, Bradford and the Puritans had turned their backs on the sea, so as to set their light on a hill. At the same time, the development of the Atlantic seaboard of North America was accomplished, first, by going back to sea. The Pacific Ocean was, of course, already known, its eastern edge having been sighted by Balboa (rather than

\footnotetext{
${ }^{1}$ Sir Paul Harvey (ed), The Oxford Companion to Classical Literature, Oxford: OUP, 1962.

${ }^{2}$ Introduction to Peter Neill (ed), American Sea Writing: A Literary Anthology, Library of America, 2000.

${ }^{3}$ Ibid.
} 
Keats's 'stout Cortez') at the Isthmus of Panama in 1513. He called it Mar del Sud. It was the Portuguese captain, Magellan - the first of many explorers to perish while mapping the ocean - who bestowed the name that abides - Mar Pacifico in Portuguese - the Pacific Ocean.

This is the largest of the world's oceanic divisions, covering 165.25 million square kilometres with a volume of 622 million cubic kilometres. To put these figures more intelligibly, the Pacific stretches from the Arctic in the north to the Southern Ocean and Antarctica, from Asia and Australia to the Americas. It covers $46 \%$ of the earth's water surface and a third of the whole surface of the globe. That is, it is larger than all the world's land area, with room for another Africa. Land occupies less than one percent of the surface area of the Pacific Ocean. It is found as continental islands, high islands, coral reefs and uplifted coral platforms. New Guinea is the largest landmass wholly within this ocean. Its European discovery belonged to the Spanish in the seventeenth century. As Stuart Macintyre comments, 'the British were laggards in the Pacific. The Spanish, Portuguese and Dutch preceded them into the archipelago that descends down its western fringe. Spain also held the eastern extremity from the Strait of Magellan up to California' ${ }^{4}$. But in the eighteenth century, the British and the French did come into the Pacific - to Tahiti, to New Zealand and to the east coast of Australia.

When, late in that century, British settlement began in New South Wales, for reasons that have been over-disputed, but in whose mix strategic considerations figured as much as economic and penal ones, the orientation of the colony was towards the ocean, as much as towards the land. That is, the British were alert to possible French designs on this territory, even though one of their motives was also and initially 'not an occupation of the Australian continent but rather an investiture of the South-West Pacific with new stations for Britain's expanding presence east of India'. Thus the Pacific figured altogether differently in Australia's early colonial history than did the Atlantic in that of the United States. The demographics shifted as well. Whereas much of the American continent from one oceanic coast to the other was, because it could be, populated, from 1788 'the great mass of the Australian people have always lived on the eastern seaboard, facing the Pacific, and its islands have drawn them as traders and missionaries, administrators and adventurers'

That assertion is sound, but one of the paradoxes explored here is how few in number were the Australian writers who have been drawn to the Pacific and its islands. The Indian Ocean littoral has been, perhaps, as compelling: as the site of marital unhappiness in Katharine Prichard's Intimate Strangers (1937) and her Broome pearling pot-boiler, Moon of Desire (1941); in Randolph Stow's The Merry-Go-Round in the Sea (1965), set in the coastal town of Geraldton where he grew up; in historical fiction of the horrors that followed shipwreck of the Batavia in 1622 by such writers as Arabella Edge in The Company (2003); in the novels, short stories and memoirs (most recently, Montebello, 2012) by Robert Drewe of his childhood and youth by the Indian Ocean. In Romy Ash's novel, Floundering (2012) that ocean is the point from where one can run no farther in Australia. The Pacific Ocean has had more sway with poets than the Indian, whether with Bernard O'Dowd's grotesque description of 'Australia' as 'last sea-thing dredged by sailor Time from Space', or James McAuley writing of the vision of the Spanish explorer and evangelist de Quiros in 'Terra Australis': 'Voyage within you, on that fabled ocean,/And you will find that Southern Continent'. And then there is Kenneth Slessor, making yet more momentous James Cook's turning of his ship

\footnotetext{
${ }^{4}$ Stuart Macintyre, A Concise History of Australia, Melbourne: CUP, 1999.

${ }^{5}$ Ibid.
} 
in 1770 out in the Pacific: 'So Cook made choice, so Cook sailed westabout,/So men write poems in Australia'.

The Australian novelist Christina Stead came to live at Pacific Street, Watson's Bay in 1917 (the year that she turned fifteen). Nearby, ships leaving Sydney Harbour pass through the Heads into the Pacific. In a radio interview in September 1979, Stead recalled how 'in big storms the spray from the Gap used to come right on the roof of our house. It's close the ocean. And all the ocean liners, and other ships, mercantile ships and so on, came right in front of our house' ${ }^{6}$. The suburb is depicted as Fisherman's Bay in Stead's novel, Seven Poor Men of Sydney (1934) and Michael Bagenault, one of those seven poor men, jumps to his death from the Gap. Her novel, For Love Alone (1944) begins with an ecstatic Preface titled 'The Sea People' that celebrates and insists upon Australians' orientation outward to the Pacific, rather than inland to "plains heavy with wheat, then the endless dust ... Sahara, the salt-crusted bed of a prehistoric sea, and leafless mountain ranges. There is nothing in the interior. So people look toward the water, and above to the fixed stars and constellations which first guided men here'.

Stead prefers to map an 'island continent [that] lies in the water hemisphere'. She continues: 'On the eastern coast the neighbouring nation is Chile, though it is far far east, Valparaiso being more than six thousand miles away in a straight line; her northern neighbours are those of the Timor Sea, the Yellow Sea; to the south is that cold stormy sea full of earth-wide rollers, which stretches from there without land, south to the Pole'. There is another world, 'the old world, the land hemisphere', which is 'far above her as it is shown on maps drawn upside-down by old-world cartographers. From that world and particularly from a scarcely noticeable island up toward the North Pole the people came'. They came, in Stead's words, to 'a fruitful island of the sea world, a great Ithaca'. To the race that formed there she declares "can be put the famous question: "Oh, Australian, have you just come from the harbour? Is your ship in the roadstead? Men of what nation put you down - for I am sure you did not get here on foot", 7 . The complex fate that, Teresa Hawkins, Stead's protagonist in For Love Alone embraces (as had her creator) is to cross that water hemisphere for the old, other world, reversing the journeys of the early venturers.

As Stead exulted in Australia's prime place in the water hemisphere, the three poets celebrated what might befall when land was come upon from the ocean in ways that brimmed (as she had) with optimism. McAuley would in life make many crucial turns back across the ocean, to New Guinea, during and after the Second World War. Apart from the war, the main cause of Australians' orientation towards the Pacific was trade, sometimes in spices and sandalwood, but also - from 1863-1904 - in people. This was the recruitment, through fraud and force, of 62000 Pacific Islanders, mostly from the New Hebrides and the Solomon Islands, to work on sugar and cotton plantations in north Queensland. The Kanakas, so called and so demeaned, were part of a heartless process with a name fit for it - 'blackbirding'. One of the principal beneficiaries was the man who gave his name to Townsville. On the fringes of the business was the Australian author whose youthful career at sea had been altogether as adventurous as Herman Melville's and whose body of fiction is an unrivalled part of the Australian literature of the Pacific. He was George Lewis or Louis Becke.

\footnotetext{
${ }^{6}$ Quoted in Peter Pierce (ed), The Oxford Literary Guide to Australia, Melbourne: OUP, 1987.

${ }^{7}$ Christina Stead, For Love Alone, New York: Harcourt, Brace, 1944.
} 
In 1869 , at the age of fourteen, he accompanied his brother on a voyage to the United States. His account of 'the nightmare 130-day voyage in a leaking barque with a mutinous crew may well be Becke's first incursion into fiction'. After returning to Australia, he stowed away on the Ratumah. From Samoa he worked as a trader, part of whose business was running guns. In 1874, he joined the crew of the notorious American-born William (Bully) Hayes's ship, Leonora. Its mission was blackbirding. After the ship was wrecked, Becke was arrested, taken back to Australia, tried and acquitted in Brisbane. By 1880 he was trading again at Nanumanga in the Ellice Group. The following year found him in New Britain, 'one of the most savage regions in Melanesia, and a far cry from the languid charms of Polynesia'. When Becke's first story was enthusiastically accepted by JF Archibald for publication in the Bulletin, 'the Rudyard Kipling of Australia', took up a more sedentary, if still amorously complicated career. He would come to describe for Australians and then for readers around the world, what the South Australian Register of 1896 called 'the lonely islands of the wide Pacific'. This was a region of which those readers thought they knew a little, but of which he had much more to tell them.

Becke's travels and his fiction map the Pacific 'water hemisphere' that Stead had imagined. His titles and sub-titles plot a course to and fro among the island of the Pacific: 'A Story of the Marquesas', 'A Memory of Paumotu', 'A Mid-Pacific Sketch', 'In Noumea', 'A Tale of Easter Island', 'A Memory of the Eastern Pacific'. If Becke was the laureate of 'reef and palm' (his first volume of stories, published in 1894, was By Reef and Palm) and the mythologiser of the languidly romantic island landscapes of the Pacific, he also wrote with 'the authority of one who had seen the violence, the wrecking of lives, the acts of revenge, the brutal exchange of women for goods that comprised the underside of the Pacific idyll, ${ }^{8}$. The most common form of the stories, congenial to the Bulletin, was the yarn. Adventure motifs are employed - castaways at sea in an open boat, mutinies, cannibal feasts - but Becke has a moral and satirical purpose as well. Numbers of his characters are in flight from Australia, domesticity and faithless wives. They find, in partnering with native women, that 'changes of latitude may enable shifts away from conventional arrangements', that 'in the South Seas, as in Australia as elsewhere, to get a girl of your heart is generally a mere matter of trade'. Australia's ablest and most prolific writer about the Pacific, Becke also shares in the sceptical inquiries into marriage of his contemporaries, Barbara Baynton, Henry Lawson and Rosa Praed.

Although he worked in New Britain, one of the islands of New Guinea, Becke had little to say of the place. In that, he was not singular. Australia's nearest neighbour, and the greatest of the Pacific islands, has been strangely neglected by our writers. There was a tinge of desperation in the title of Nigel Krauth's 1982 collection of New Guinea Images in Australian Literature. Not included there was one of Becke's adventurous successors, a Tasmanian-born teenager who came to New Guinea in 1927 to train as a district officer. Errol Flynn would also work as the overseer of a copra plantation, as a gold prospector and partner in a schooner charter business. In 1930 he bought the cutter Sirocco in Sydney and sailed at leisure back to New Guinea where he managed a tobacco plantation at Laloki and wrote the columns for the Bulletin that furnished his first book, Beam Ends (1937). By 1932 Flynn was back in Sydney, notorious for his bad debts in New Guinea, but handsome enough to be hired to play Fletcher Christian in Charles Chauvel's first talkie, In the Wake of the Bounty (1933). Chauvel had filmed some of its scenes in Tahiti, film that was confiscated for its depiction of bare-breasted native women. Flynn took part in the re-enactment scenes at Bondi. His Pacific

\footnotetext{
${ }^{8}$ Peter Pierce, Introduction to Louis Becke, By Reef and Palm, Rowville: The Five Mile Press, 2005.
} 
engagements ended in 1959 when he died in Vancouver, far away, on the other side of the Pacific.

New Guinea would play its largest literary part for Australian writers because of the Second World War, the 'Jap and Jungle' fiction of Osmar White, Green Armour (1945), Tom Hungerford, The Last Blue Sea (1952), Jon Cleary, The Climate of Courage (1954), Norman Bartlett, Island Victory (1955) and 'David Forrest', The Last Blue Sea (1959). The outstanding memoir is Peter Ryan's Fear Drive My Feet (1959). RAAF poet David Campbell wrote both memoir and the notable poems 'Men in Green' and 'Pedrina'. Official war correspondent, Kenneth Slessor left one theatre of war in the Middle East for another, nearer home. In 'New Guinea: The Twilight War' (1943) he wrote of how Australians and Americans 'plunged into this obscure struggle for survival, have long since found that their enemies are not the Japanese alone ... The jungle has deadlier adversaries than the Japanese. It hits back at the fighting man with sharp claws, with matted roots and vines and thorns, with tiger-toothed branches and barbed undergrowth; it mocks him with tremendous ribs of mountain, with vertical peaks, deep torrents, agonies of rock and marsh; it soaks him to the hide with whipping rain, it saturates him with sweat, it burns him with incandescent heat and fevers, it cakes him with a pulp of loathsome mud" ${ }^{9}$. Fights over censorship (and, one suspects, his derisive poem about General Blamey, 'An Inscription for Dog River') meant that Slessor resigned his post as war correspondent. He had this last thing to say about the war and New Guinea's place in the Pacific: 'To understand this kind of country and this kind of war, you must abandon all visions of tropical islands, white beaches, waving palm trees, tinkling music, romantic moonlight. New Guinea is not that kind of island at all'.

Yet it filled James McAuley with wonder. In 'New Guinea', from A Vision of Ceremony (1956) he invoked a

Bird-shaped island, with secretive bird-voices,

Land of apocalypse, where the earth dances,

The mountains speak, the doors of the spirit open,

And men are shaken by obscure trances.

The forest odours, insects, clouds and fountains

Are like the figures of my inmost dream,

Vibrant with untellable recognition;

A wordless revelation is their theme. ${ }^{10}$

New Guinea was also the island that attracted Trevor Shearston as a graduate teacher in 1968 and gave him material for his first novel, Sticks That Kill (1983). More recently, he drew on the 1877 journey up the Fly River by the Italian naturalist, Luigi d'Alberti, for Dead Birds (2007) a novel narrated from the point-of-view of the severed head of one of the natives. Randolph Stow set his novel, Visitants (1979) in Papua. Drusilla Modjeska, who spent her early years in New Guinea before coming to Australia in 1971, used those experiences for her first novel, The Mountain (2012), a muted, small-scale epic of the years leading up to the independence of Papua New Guinea, and its aftermath. She maps the territory in various ways, showing how it has been imagined and possessed. One map included in the text simply depicts the region of mountains and fjords on the north coast of the southern part of the island. Another is the Surrealists' Map of the World. First published in a special issue of the Brussels magazine Varietes entitled Le Surrealisme in 1929, it shows New Guinea dwarfing

\footnotetext{
${ }^{9}$ Reprinted in Kenneth Slessor, Bread and Wine: Selected Prose, Sydney: Angus \& Robertson, 1970.

${ }^{10}$ James McAuley, A Vision of Ceremony, Sydney: Angus \& Robertson, 1956.
} 
Australia. The Ile des Pacques is nearly the size of the South American continent. The Pacific Ocean that so entranced the imagination of the Surrealists, as it had Christina Stead's, is central.

Let us stay in that ocean and reverse Cook's voyage of 1770 to travel back from New Guinea and eastern Australia to New Zealand, the second most populous group of islands in the Pacific. Despite Thor Heyerdahl's attempt to prove, by the Kon-Tiki expedition of 1947, that Polynesia had been settled from South America, by voyages east across the Pacific, the migration that ended in New Zealand had probably begun in south-east Asia. The Maori are thought to have reached New Zealand in the thirteenth century. They would wait 400 years before they encountered Europeans. On 18 December 1642, two ships of the Dutch East India Company, Heemskerck and Zeehaen, commanded by Abel Tasman, saw the light of many fires on the New Zealand coast. Having left Batavia in August, the ships had sailed south through the Indian Ocean, steered east into the Southern Ocean, missed the Australian continent entirely, but made brief landfall in the south of the place that Tasman (whose name it would eventually bear) named Van Diemen's Land. The crew saw smoke, heard singing, but no people showed themselves. Sailing on, eight days later they discerned 'a large land, uplifted high'. Tasman named it New Zealand. The next name that he bestowed was Murderers' Bay, after an attack on his crew by Maoris in canoes. It would be 127 years before Europeans returned to New Zealand.

In 1942, a small memorial volume to celebrate the $300^{\text {th }}$ anniversary of Tasman's arrival in New Zealand waters included Allen Curnow's poem, 'Landfall in Unknown Seas'. It begins 'Simply by sailing in a new direction/You could enlarge the world'. Curnow continues:

Between you and the South an older enmity

Lodged in the searching mind, that could not tolerate

So huge a hegemony of ignorance.

There, where your Indies had already sprinkled

Their tribes like ocean rains, you aimed your voyage;

Like them invoked your God, gave seas to history

And islands to new hazardous tomorrows.

Curnow guesses at the responses of the Maori to the disturbing appearance of the two great ships in the bay: 'Always to islanders danger/Is what comes over the sea'. And so it often proves. In the last line of the poem, Curnow identifies 'The stain of blood that writes an island story ${ }^{11}$. His concern is with the motives for, and consequences of European exploration of the Pacific. But what can we guess of that experience for them?

Christina Thompson has imagined how, practically, the Europeans in the Pacific first viewed the land from the sea. They 'recorded it in gently undulating profiles, taking note of any distinctive formations that might prove useful to future navigators. To them it was a stretch of rocky coastline, miles of inscrutable grey-green bush, a series of possible landfalls, inlets and bays where one might get water, reefs and sandbars to avoid'. Then there was the management of human contact, with the certainty of mutual misunderstanding, whether its results were benign or bloody. In the case of Tasman and his crew, New Zealand was a hostile, dangerous place. But Thompson also considered - as did Curnow - the matter of

\footnotetext{
${ }^{11}$ Included in The Auckland University Press Anthology of New Zealand Literature, eds Jane Stafford and Mark Williams, Auckland: AUP, 2012.
} 
what the Maori thought. The title of her book is Come on Shore and We Will Kill and Eat You All (2008) ${ }^{12}$. This comes from a perhaps misreported threat to Cook and his crew on their first visit to New Zealand in 1769. In any event, it suggests the view from the land to the sea, the Maori apprehensiveness about the first strangers in their waters in living memory.

Thompson also writes eloquently of Maori memories of where they had come from, after first venturing thoughts of the European experience: 'for the voyaging European, the Pacific was a vast, inscrutable emptiness, an endless horizon, a sky full of light. It was the opposite, in every respect, of the place he called home, a cozy, terrestrial cluster of cities and farms, busy with human activity. The Pacific, by contrast, seemed dreamlike, a liminal space, a place of clouds and shadows'. Then she addresses the converse. What was the Polynesian remembrance and mythologising of the places that they had long ago left behind? Thompson argues that 'All over Polynesia the specific memory of where they had come from and how to get there disappeared, leaving no more than an echo, a myth of an ancestral homeland reachable only by supernatural means. In the Maori tradition this land is Hawaiki ... an otherworldly place, sometimes in the east, sometimes in the west, sometimes in the sky or under water. It is a land of origin and a source of life, a place of plenty, a paradise. But it is also a place of death and separation, and those who pass over to Hawaiki are lost to this world'. This is the mordant counterpart to the notion of a paradise in the Pacific. Europeans, then unaware of notions of Hawaiki, would think that they had found a paradise, far to the east.

Cook on the Endeavour arrived at what he named the Society Islands on 13 April 1769 and stayed till 9 August. In the Introduction to his edition of Cook's journals, JC Beaglehole famously praised the island that Bougainville had named New Cythera after the place where Aphrodite rose from the waves. It would become known as Tahiti, a version of Otaheite, its native name. Beaglehole wrote 'Green stood up that island in the sea, not with the pale intense jewelled green of shadows above a reef, spirit-beguiling and traitorous amid the soft depths of blue; but with the green of groves that root in the soil, of a spontaneous growth that flung abroad the perfume of earth and fruit and flower'. He concluded: 'Wallis [first European to discover Tahiti - in 1767 - Bougainville came the next year] had not merely come to a convenient port of call. He had stumbled on a foundation stone of the Romantic Movement. Not as continent, not as vast distances, was the ocean henceforth in common thought to be known. The unreal was to mingle with the real, the too dramatic with the undramatic; the shining light was to become a haze in which every island was the one island, and the one island a Tahitian dream ${ }^{13}$. More prosaically, Thompson writes of Wallis's arrival at Tahiti that 'to the tired, grubby, hungry sailors who discovered it, Tahiti seemed a paradise on earth'.

That paradise was almost as soon lost as found. Wallis, Bougainville and Cook all had violent encounters with the natives of Tahiti. The island also quickly found itself within a web of European commerce as well as spinning its own web of enchantment. The painter and naturalist, John William Lewin, author of Birds of New South Wales (1813), the first illustrated book to be published in Australia, arrived in the colony in 1800. He missed the boat on which he should have sailed with his wife and did not reach Sydney until a year after her, to find that she was under suspicion of criminal conversation with the second mate of the Buffalo. In 1801, Lewin undertook three expeditions for Governor King, the last and longest of which was on the brig Norfolk that left in November 1801 for Tahiti to buy salt pork for

\footnotetext{
${ }^{12}$ Christina Thompson, Come On Shore and We Will Kill and Eat You All, London: Bloomsbury, 2008.

${ }^{13}$ Quoted in Bernard Smith, European Vision and the South Pacific 1768-1850, Oxford: OUP, 1962.
} 
the still ill-provisioned settlers of New South Wales. On 25 March 1802, the ship was wrecked at Point Venus (so named because here Cook observed the transit of Venus on 3 June 1769). Lewin and his companions found themselves embroiled in a civil war between King Pomare I and the surrounding islands. For months they were, in his words, 'alarmed with the Dreadfull idea of having our throats cut ${ }^{\text {, }}{ }^{14}$.

Lewin got safely back to Sydney at the end of 1802, burning with contempt for 'those dastards called missionary they would have run and hid themselves rather than fight or protect their property or wife'. Only a few decades after the first European visits to this earthly paradise, a paradise not of this earth was being preached to the Tahitian and other peoples of the Pacific. Herman Melville joined in the chorus in his 'Peep at Polynesian Life', Typee (1846) and was seconded by Robert Louis Stevenson and by Becke who denounced their converts as 'the repellent, canting, native [missionaries] of Micronesia'. They excoriated (and were berated in turn) the activities of Christian missionaries in what had been once, if briefly thought to be unfallen places. Nevertheless, the notion of Tahiti in particular as Paradise continues to be examined, for instance in two memoirs written in this century. Larry McMurtry's is bluntly called Paradise (2001) ${ }^{15}$, while Australian author and serial expatriate Sarah Turnbull wrote All Good Things $(2013)^{16}$ in large part about her stay in Tahiti.

McMurtry flew to Tahiti and then travelled around the Paumotu and Marquesas Islands in the freighter Aranui. He knows that among others (Cezanne notably) he is following Gauguin: 'I have come to the same paradise - Tahiti - a place whose beauty neither writers nor painters nor mariners have ever managed to overstate'. He seeks out a culture that is neither American, European, nor Asian: 'the culture of the sea places of Oceania'. Of Gauguin, McMurtry reckons that he 'looked hard at the earthly paradise, both in Tahiti and in Ahuona, and saw that it was sad. He looked as hard as anyone has at the languor, into the hopelessness, at the edge of fleshly things'. McMurtry judges that 'the problem with paradise is monotony', and he thinks of actors who have gone so far as to own islands in the Pacific Marlon Brando and Martin Burr: 'they owned their own pieces of paradise and yet, in both lives, paradises didn't help much'.

Turnbull's sampling of paradise in modern Tahiti (a place for McMurtry where 'paradise is on welfare - French welfare') was more protracted. When her husband's Paris law firm asked him to open an office in Tahiti, she came there with him to live. She sought bearings: 'the territory floated in a vast oceanic no-man's land between South America and the east coast of Australia'; 'on the world map French Polynesia looked like punctuation - entirely optional'. Turnbull and her husband settled on Moorea, an island fourteen kilometres across the bay from Papeete. She writes, wryly, of 'Sumptuous sunsets. Palm-fringed private beach. Lagoon on our doorstep. Sweet papaya by the bagful. Vanilla beans bundled up like lush and fragrant firesticks. I know, I know. Paradise'. There is already an undertone of weariness and ambivalence. Turnbull learns of the local malady called fui, where one is 'fed up/tired/flat/over it/over everything'. If it is the case that 'throughout the ages, earthly paradise has always been a walled garden or an island - a separate little world' - yet she cites the caution from Thurston Clarke in Searching for Paradise: 'Every remote island is a potential Alcatraz'. Turnbull knows that she is able to leave, having been only a sojourner in

\footnotetext{
${ }^{14}$ Richard Neville, Mr JW Lewin: Painter and Naturalist, Sydney: Newsouth, 2012.

${ }^{15}$ Larry McMurtry, Paradise, New York: Simon \& Schuster, 2001.

${ }^{16}$ Sarah Turnbull, All Good Things, Sydney: HarperCollins, 2013.
} 
Tahiti, if an astute and sympathetic respondent to its beauties and to its psychological malaise.

Turnbull is aware of how that malaise can infect those who have come to the islands of the Pacific as well as those who are native to them. The deliverance promised by landfall could be illusory. Many could come to see themselves as castaway and if they could, would move restlessly elsewhere. As Turnbull shrewdly remarks of Tahiti, 'Perhaps the problem was that there were too many comings and goings for a faraway island'. The mirage of the Pacific islands as Paradise would appear and disappear across the centuries. At the same time, as Turnbull says, Tahiti 'seemed to tap into a huge human longing'. Or perhaps more than one: there were passionate longings for discovery, conquest, escape, sanctuary, sensual pleasures (however soon dulled). These are some of the fecund complications of the literature of the Pacific, mainly Australian, that has been explore here.

Let us end this eastward tour of the Pacific by heading sharply west, in order to end on the east coast of Australia. In 1964, Barry Humphries wrote a song for the character Barry McKenzie whom he had created for the comic strip drawn by Nicholas Garland for the British satirical magazine Private Eye. A recording of the song was attached to the Christmas edition. In his show 'Excuse I' (1965), Humphries - as the surf addict Nipper Dixon performed the song on stage. Barry Crocker would sing it in the 1972 film 'The Adventures of Barry McKenzie'. Australia's most famous drinking song, 'The Old Pacific Sea', ends this way - you may join in the chorus:

I've had liquid laughs in bars, and I've hurled from moving cars, And I've chundered when and where it suited me.

But if I could choose the spot

To regurgitate me lot,

Then I'd chunder in the Old Pacific Sea.

Drink it up, drink it up,

Crack another dozen tubes and prawns with me,

If you want to throw your voice,

Mate you don't have any choice,

But to chunder in the Old Pacific Sea. 


\section{Works Cited}

Sir Paul Harvey (ed), The Oxford Companion to Classical Literature, Oxford: OUP, 1962

Douglas Hunt, 'Writing About Blackbirding', paper presented at the 'Tropics of the Imagination' conference at James Cook University Cairns, July 2013

Stuart Macintyre, A Concise History of Australia, Melbourne: CUP, 1999

James McAuley, A Vision of Ceremony, Sydney: Angus \& Robertson, 1956

Larry McMurtry, Paradise, New York: Simon \& Schuster, 2001

Peter Neill (ed), American Sea Writing: A Literary Anthology, Library of America, 2000

Richard Neville, Mr JW Lewin: Painter and Naturalist, Sydney: Newsouth, 2012

Peter Pierce, Introduction to Louis Becke, By Reef and Palm, Rowville: The Five Mile Press, 2005

Peter Pierce (ed), The Oxford Literary Guide to Australia, Melbourne: OUP, 1987

Kenneth Slessor, Bread and Wine: Selected Prose, Sydney: Angus \& Robertson, 1970

Bernard Smith, European Vision and the South Pacific 1768-1850, Oxford: OUP, 1962

Jane Stafford and Mark Williams (eds), The Auckland University Press Anthology of New Zealand Literature, Auckland: AUP, 2012

Christina Stead, For Love Alone, New York: Harcourt, Brace, 1944

Christina Thompson, Come On Shore and We Will Kill and Eat You All, London: Bloomsbury, 2008

Sarah Turnbull, All Good Things, Sydney: HarperCollins, 2013 